\title{
Social and Cultural Conditions of Communities Around Mining Areas (Potential Conflicts Around Tokatindung Mining Area)
}

\author{
Ferdinand Kerebungu 1,*, Siti Fathimah ${ }^{2}$, Sanita Carolina Sasea ${ }^{3}$
}

\author{
1,2,3 Universitas Negeri Manado, Manado, Indonesia \\ *Corresponding author.Email: ferdinankerebungu@unima.ac.id
}

\begin{abstract}
Social conflict is a social phenomenon that is often observed in co-life and the cause of occurrence can be caused by various problems that are happening in society. Such conditions are not desired by many people, but because of the situation and conditions that exist in a society that causes social conflict, and the conflict is increasingly worrying if it leads to destructive conflicts. Therefore, the problems in the research can be formulated as follows; "Why is there an agrarian conflict in Lolak Subdistrict?" The purpose of this study is to describe the factors causing agrarian conflict between the community and PT. Anugerah Sulawesi Indah (PT ASI) in Lolak Subdistrict, Bolaang Mongondow Regency. The method used by this research with data collection techniques through the observation and interview process. Based on the discussion of the results of the research can be presented some of the findings in this study are: 1) Conflict occurs due to differences in viewpoints between farmers and HGU land processors namely PT ASI, 2) The unoccupied government as a facilitator with the farming community, 3) in the event of resistance of the farming community, the government of Bolaang Mongondow district cannot provide a solution that can be accepted by both parties. To be concluded that the occurrence of agrarian conflict in Lolak Sub-district is caused because between farmers, PT ASI and the Local Government there is not agreed on the issue of land acquisition and utilization.
\end{abstract}

Keywords: Agrarian Conflict, Conflict Solutions, and Vertical Conflict.

\section{INTRODUCTION}

After the collapse of the New Order, Indonesian people's lives seemed uncontrolled and controlled. This condition can be observed since 1998 often the occurrence of conducive situations, wherein the midst of people's lives we encounter an uncertain life due to frequent terror and horizontal and vertical conflicts alternately color the lives of Indonesians, such as conflicts in Aceh, Papua, Poso, Sambas, and Maluku. Such conditions describe if our society has values and social norms that can control their patterns of behavior.

The government seems to let conflict flourish in Indonesia, such as mushrooms in the rainy season. Even if there are efforts to resolve the conflict but not faced seriously to solve the problems faced by the community to the core of the cause of the conflict. The phenomenon of conflict in Indonesia [1], gives an idea of the condition of people who do not trust the government anymore, due to the system of government that does not favor the community.

The condition can be seen where the executive prefers the interests of the legislative party, while on the other hand the legislative party always on behalf of the constituents to smooth the bargaining with the executive, so APBN or APBD absorbed much not for the public interest. For example, the government (executive and legislative) often conducts comparative studies both in and out of the country, but there are no state or local results and expenditures. This phenomenon often encourages people to do anarchy, due to a lack of public trust in the government, because the government does not pay attention to the most basic needs of society.

One of them is the case of limitations and abundance of natural resources to be some of the triggers of renewable natural resource conflicts in Jakarta bordering Indonesia and Malaysia. There is a fundamental difference between the conflict of renewable natural resources and unrenewable natural resources especially in the border areas. Renewable natural resource conflicts are cyclical, whereas non-renewable conflicts of resource conflicts only apply temporarily in the same location [2]. Not only that the case in Donggala Regency of Central Sulawesi also experienced disputes, where the resistance of lindu indigenous peoples in the palu-3 hydropower development plan and the central Sulawesi provincial government [3], similar cases also occurred in various 
countries namely the promotion of mining by the Korea government has led to an escalation of conflict at certain mining sites, as well as the intensification of public debate on the relationship between resource extraction and development. His paper also compares the context of two different mining sites in Ecuador, the Mirador Project at Zamora Chinchipe and the Intag in Imbabura to analyze how territorial dynamics play a role in the conflict and influence the local response to mining [4].

Similarly, the case of Buyat Bay, where the problem in this region is pollution caused by gold processing waste from gold mines to be carried out by PT. MSM. Buyat Bay conflict is also common around the mining area, whether in the context of contesting the mining area by illegal miners/PETI, or between groups of entrepreneurs with the mining management community (tatelu case 2002) or with landowners who become a mining area managed by large and small and mediumsized companies. Mining areas such as gold, coal, tin or other types of minerals often invite conflicts, both vertical and horizontal conflicts. The conflict can be seen such as the case of Pongkor, Cikotok, Bangka and Belitung, Tembagapura, Verbek, and so forth.

In North Sulawesi Province the same case has also occurred in Ratotok Subdistrict of South Minahasa Regency (now Southeast Minahasa Regency) known as Buyat case, which is in the form of vertical and horizontal conflict. The conflict was triggered by the dissatisfaction of the citizens over the development of land compensation that became the mining area of PT MNR, but also triggered by the dissatisfaction of residents who were laid off due to the rationalization of employees, and even conflicts between citizens with the government and citizens with PT. MNR. It is also felt by the Chinese, where the consequences of underground mining in China have led to a severe decline in the land that led to the forced eviction of millions of farmers. It was found that the farmers who were relocated as a whole did not receive adequate compensation for the damage caused by the mining [5].

In principle in North Sulawesi Province has natural wealth in the form of agricultural products, fisheries, and mining. Especially the natural wealth of the mining sector until now has not been processed to the maximum as one of the regional sources of income that can absorb a considerable amount of labor. The mining sector in North Sulawesi province is new in Ratatotok that has been processed to the maximum by PT MNR so that they can provide perpetual funds for the minahasa community and PT Avoser in Bolaang Mongondow Regency, but most are still managed traditionally (PETI) so that the nature of individuals and does not have a positive impact for development in this area to the maximum because it is only enjoyed by a small percentage of people, and even have an impact on environmental pollution that is so dangerous because gold processing waste is not managed using standard technology in the waste treatment industry.

In recent vertical conflicts between the Governor of North Sulawesi Province and PT MSM, related to the case of gold mining operation permits in North
Minahahasa Regency. The conflict is related to the issue of the AMDAL controversy of PT MSM, where on the one hand the Minister of Energy and Mineral Resources grants operating permits while on the other hand the Minister of Environment does not allow PT MSM to operate based on environmental issues and the other hand the Governor on behalf of the people of North Sulawesi does not provide recommendations for the operation of PT MSM.

By not allowing PT MSM to operate, the community around the mine is losing jobs. The surrounding community recruited by PT MSM to be employees of approximately 1000 people and at this time approximately 600 employees who are homeless await certainty from the local government whether PT MSM is allowed to operate or not, otherwise, it will be the tone of 1000 unemployed people in North Minahasa Regency, and if allowed then there will be an increase in labor. This condition is very ironic, on the one hand the government boosts the local native income (PAD) and seeks investors to cultivate the natural resources contained in this area and create jobs for local communities, but on the other hand the government does not allow investors to manage natural resources, so there is no creation of jobs.

In principle the operation of a company in an area aims to employ the surrounding community whether they are as a brute force or technician. The higher the investment will have a very positive impact on the surrounding community in other words the surrounding community will experience improved welfare. In local media reported that the community of Marinsouw Village is one of the villages around the mining PT MSM stated the loss of jobs as a result of the government's rejection of the operation of PT MSM, according to a statement from members of the Marinsouw Village community that they currently do not have a permanent job anymore because they have been housed by PT MSM because it is not yet operational.

This paper will be reviewed about the socioeconomic condition of the community of 11 villages located around the mining site of PT MSM namely Wineru Village, Maen, Winuri, Marinsouw, Kalinaun, Rinondoran, Pantepasar, and Pinenek to 9 villages are located in the District of East Likupang North Minahasa Regency. Meanwhile, Tinerungan and Pinasungkulan villages are located in North Bitung District, Bitung City. This assessment is intended to obtain a real picture of how the socio-economic condition of the community around the mining area of PT MSM, so that if in the future this mining company is allowed by the government to operate then the hue of the community has been obtained, and if in the future the company ceases to operate there is a benchmark to know the extent of the company's contribution to the surrounding community, whether there is an improvement in welfare or not. Thus, the research problems to be studied in this paper are related to the problems and solutions of gold mining in North Minahasa. 


\section{LITERATURE REVIEW}

Research study about the social conflict within the mining area has been carried out, among them are the writings of Chang Hoon $\mathrm{Oh}$ and comrades, in the research tried to analyze the characteristics and causes of conflict mining through descriptive analysis by using a two-case comparative and 162 conflicts between mining companies and communities that occurred during the year 2012-2013 in 44 countries. By using the case analysis of two cases of mining conflicts in Peru and Chile [6].

So also with Fiorella Triscritti [7] in his writings discuss Peru as the largest gold producer in Latin America since 1996. It is mainly caused by the gold mining open-pit mine in the northern region of Ancash, Cajamarca, and La Libertad, which is managed by Barrick Gold Corporation and Newmont Mining Corporation. The expansion project of large-scale mining has provoked protest and social conflict, which is caused by the context of weak institutions as well as at least the supervision of the central government.

Some of the research is on top to be the reference for this study, namely the social and cultural conditions of the community around the area of mining. However, this study is focused on the situation of the conditions of social conflict in the area around the mines in the Mining Tokatindung. Different from previous research, in addition, to discussing the conditions of social conflict surrounding communities, this study also examines the social conditions of the culture of the local community.

\section{METHOD}

The research method used is the qualitative research method using the case study approach. According to Maxfield [8] Case study, or case study is a study of the status of a research subject who is pleased with a specific or typical phase of the overall personality. Data collection techniques are direct observations and interviews.

\section{RESULTS AND DISCUSSION}

In each area there will be an acculturation process and this process will end in the acceptance or rejection of a new element of foreign culture or culture brought by the immigrant population of a region. If there is a rejection of the elements of a culture, then what will happen is disintegration/conflict, whether vertical or horizontal conflict. But on the contrary if the new cultural element is accepted, then what will happen is the integration of culture between immigrant and local communities. In the area of PT MSM there is an acculturation process because based on observations made to the surrounding community, they do not do rejection. After all, the surrounding community feels there is receiving benefits from the inclusion of the company for the development of their culture, especially in the efforts to continue their children's education.

Each culture is basically a configuration of parts that are closely related to each other and have undergone adjustments. So the entry of each element of foreign culture usually shakes the balance on the culture that comes. The new element is usually not at once accepted by all citizens but belongs to a small group of people only. In subsequent developments the foreign cultural element was finally permanently placed in the cultural structure it came to, and there was a process of integration in culture [9].

In analyzing the integration process, anthropologists use holistic methods that are not only tasked with analyzing culture by knowing the various ways to break it down into small elements and study the elements in detail but they are also tasked to be able to understand the relationship between each small element and the whole. In other words, they must be able to understand the problem of integration of cultural elements [10]. The entry of new elements into a culture through a diffusion process, culture can take the form of physical and nonphysical culture such as technology systems, work patterns, or behavior patterns of a donor or immigrant community. So that the process of cultural integration can take the form of adjustment of the use of new technologies and adjustment of behavior patterns.

If in an industrial area (mining) there is a process of integration between the surrounding community and the owner of the company, then there will be a harmonization and acceptance between two different cultures. The integration process is a result of the reciprocity between the local population and the owner of the company, where the surrounding community gives their land to become an industrial area while the owner of the company provides capital and work for the surrounding community.

Based on the above reality, Blau shows something that is "given" which is the desire of a person to get social rewards. Blau admits not all human behavior is guided by considerations of social exchange, but he argues most of it is guided by the social exchange. Thus Blau [11] lays out two statements that must be fulfilled for behaviors that lead to social exchange, namely: (1) the behavior must be oriented towards goals that can only be achieved through interaction by others, and (2) behavior should aim to obtain means for the achievement of goals. These goals can be extrinsic rewards such as money, goods, and services, as well as intrinsic rewards such as love, honor, and beauty.

The issue that needs to be examined in this study is the existence of conflicts of interest and culture, whether it is between the central and local governments, between the central and local governments with entrepreneurs, or between entrepreneurs and the community, and between the community and the government. In this context, often conflicts occur between the central and regional governments (The Minister of Energy and Mineral Resources and Provincial Government), namely based on the "scramble" of authority related to how far the mining sector provides economic benefits for the region and society as well as for the country. In-Law No. 32-33 of 2004 , it is not very clear the limitations of the policy space that governs this issue, as a result in this Law there is a gap in the interpretation of each according to its 
interests by ignoring the interests of other parties (small people).

This pattern of conflict does not infrequently lead to the low responsibility of the organizers for the existence of existing mining excavations, including in responding to the existence of PETI. In other words, about the existence of PETI, it is not uncommon to find "kongkalingkong" (cooperation that violates the rules) that work behind the scenes, whose continuity is largely determined by how far economic benefits are obtained from the need to uphold a socio-political commitment.

Supposedly to prevent the occurrence of this conflict, there needs to be an informal approach to both private parties and government parties so that a useful agreement is formed for the community, the environment, and the private sector itself. This condition is as conveyed by Chang Hoon Oh [6], as to prevent negative consequences and to reduce corporate-community conflicts, mining companies must address the underlying contextual issues and take an informal approach to obtain and maintaining their social permits to operate. The best practice is to start a dialogue with the community involved to understand its concerns and find ways to resolve the issue.

If regional autonomy is seen from policies in the economic field, it means that through regional autonomy is guaranteed the smoothness of economic policy in the region (not centrally dependent), so that the local government has a wide opportunity to determine policies to develop its economy including optimization of the utilization of economic potential in the region. Thus regional autonomy will allow the birth of various local government initiatives to offer investment facilities, ease the business licensing process, and build infrastructure that supports economic turnover in the region.

In the context of the conflict that occurred in the Tokatindung mining area, a strong conflict occurred between the provincial government and businessmen (PT MSM), the issue that arises upfront is the issue of environmental pollution and amdal, so the government has not recommended PT MSM operate, as well as the rejection by the community (NGO) of the operation of PT MSM. Meanwhile, on the other side of the local community there is uncertainty about their work until now because there is no recommendation from the Provincial Government against PT MSM to operate, at this time the local community is approximately 600 people who are housed by the company of 1000 employees who work at PT MSM, due to the uncertainty. The condition can be seen in figure 1 below.

Figure 1. Relationship between Conflict Actors in
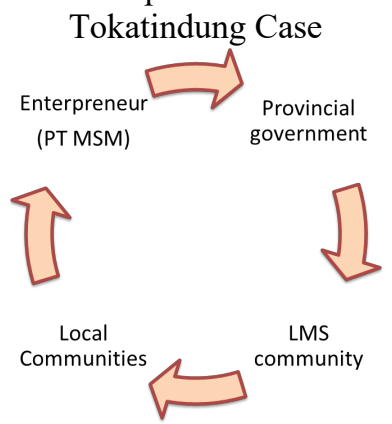

Based on the framework of inter-student relationships conceptualized through conflict mapping described above, the study will also depart from the concept of relevant theoretical understanding as commonly used to explain social phenomena that occur in society based on the concept of conflict theory. Collins [12] argued that coercion included violence as an important way to control conflict. Nevertheless, he also acknowledged the importance of unifying symbols to overcome conflicts, both on an individual, social, and structural level. Gramsci [13] Meanwhile, put pressure on the ruling class's hegemony as a form of dominance underpinned by conflict. Dahrendrof [14] further emphasizes that what underlies social conflict lies in power relations and even ownership relationships.

Coser [15] tries to explain that conflict turns out to be a vehicle for competition between groups, also serves as a vehicle for social change. While Gurr [16] through a psychological approach tries to explain the conflict with the concept of relative deprivation. This concept is differentiated into 3 types, namely: (1) decremental, which is when relative expectations remain faced with decreased reliability, (2) aspirational, which is when relative capabilities remain while expectations increase, and (3) progressive, which is when expectations increase while capabilities decrease.

Meanwhile, Crawford [17] in explaining the phenomenon of conflict in the third world has always been associated with globalization, industrialized countries and market liberalization. The thesis is mainly that third-world countries have effective local institutions to quell the conflict. However, local institutions have been weakened by the weakening of integration functions, due to the intensifying influence of globalization, industrialized countries, and market liberalization that undermines the commitment of social contracts. More chaotically, the process also followed the emergence of local political entrepreneurship or political adventurers who exploited the situation for their benefit.

Referring to the various assumptions and thesis above, it can be categorized in several explanations about the causes of conflict. Some approaches can be centered, among others: (1) realist approach, national security dilemma amid an anarchist world, (2) domestic political approach, government crisis to ensure the needs of life, security, and socioeconomic security, and (3) cultural approach, with three versions that include primordial is instrumentalist, and constructionist [18].

The realist approach sees conflicts between ethnicities occurring in mining areas as a matter of national security dilemma in an anarchist environment. In an anarchic environment full of threats, the most rational option is to prepare for resistance to defend the existence of self and group / ethnic from the threat of other parties. Self-defense from the threat of the other party will be responded to again by the other party as a threat to encourage them to take similar actions to strengthen mutual defense. In the context of aggression activities from both sides will encourage the occurrence of the exclusion of conflict, offensive attitude, war of nerves full of prejudice can lead to physical conflict between the 
conflicts. Amid constant threats, the anarchist environment, the closest social bases such as ethnicity, ethnonationalism, nation-state, and religion became the safest option for shelter.

The domestic political approach sees the conflict in the mining area stems from the incompetence and effectiveness of the government in ensuring how to meet the needs of people's lives as well as the sensitivity of the government in addressing the process of proper and unworthy mining activities. Such conditions are generally faced with a political-institutional crisis, thus encouraging community groups to build their autonomous power base, self-determination, which is an attitude arising from a crisis of public trust in the government that is no longer able to guarantee the needs of their lives or the government does not have a sensitivity to social problems faced by its people. Thus, due to the struggle in the fight for political and economic resources, so that there is an escalation of conflict between the government, society, and entrepreneurs/investors has increasingly become manifest. This is like the findings of a study by Abuya, Willice O [19] which in her findings reviews how mining-related conflicts revolve around six issues, namely: (a) land ownership; (b) "unfair" compensation; (c) unfair distribution of resources; (d) environmental degradation; (e) poverty caused by mines; and (f) conflicts of human rights violations.

The interesting thing in the social condition of this community is why the emergence of community resistance either to the government or to other parties that affects it? Or why is society so easily affected by issues either from the government or from others? The main problem so that the community is so easily affected because our community around the mining area, in general, is an agrarian society that is unable to get out of the poverty trap circle. People who have been trapped in a circle of poverty will try to find a bribe for rice. To overcome the poverty of the community there are two necessaries, first: the community itself must try to get out of the trap or the community itself must help itself. Second: the intervention of other parties in terms of providing jobs or enlightenment to the poor. The other parties intended here are the government and the private sector.

To be able to solve the first problem, how people can optimize their resources, both natural resources and human resources. The difficulty that will be faced here lies in the weakness of human resources in managing natural resources because farmers in rural communities, in general, are farmers who are based on their experiences for generations and are not able to develop themselves, because they have a low level of education. Therefore, in solving the problem, it takes the intervention of other parties to help them get out of the trap.

An important role that can be played by outsiders with the enlightenment of people who are not able to play a role in the economic field so that the poor can get out of the trap of poverty, including providing jobs for those who do not get jobs or providing training in agriculture so that they can optimize their agricultural land. In addition, other efforts that can be done are the inclusion of private or foreign parties to provide business capital for farmers / rural communities. The role of the private sector can be in the form of providing business skills or opening new jobs for the community. Thus they can get out of the trap of destitution because there has been a process of empowerment to the poor.

One form of empowerment that can be done is through environmentally sound development. As we know that North Minahasa holds a lot of natural wealth, both renewable and irrevocable. This paper will be listed the issue of how to process environmentally friendly waste from non-renewable produce (gold). Environmental pollution problems are often associated with industrial waste, especially in the mining industry. This problem is a result of development activities where each development activity will have an impact on environmental damage, either directly or indirectly. Therefore, a policy is needed by the relevant parties to regulate environmental processing issues, so that the damage that occurs does not bring too much impact including economic losses to the local community.

Emil Salim [20] suggests that non-renewable processing of natural resources needs to take into account: (1) the limitations of the number and quality of natural resources, (2) the location of natural resources and their influence on community growth and regional development, (3) the use of natural resources so as not to waste, and (4) the negative impact of processing in the form of waste is solved wisely including where to dispose of it. Then related to the problem in this paper, namely the disposal of heavy metal waste that will be implemented by PT MSM in East Likupang, it will certainly boil into the sea.

It is wise if every decision-maker and processor of natural resources pay attention to the factors that need to be considered in processing natural resources that have been previously stated. However, whether intentionally or not, there is still environmental damage (demarcation) due to the processing of natural resources that are not environmentally sound. With environmental damage, I Nyoman Beratha [21] presents 6 main causes that cause environmental problems or environmental destruction, including:

1. Lack of information on the principles of the ecosphere and ecological principles that are closely related to health, stability, and quality of life.

2. Not yet known and understood by the public about the importance of environmental quality.

3. Growth of industrialization and application of technology in the framework of modernization. The growth and development of industrialization is an action that must inevitably be implemented to exploit natural resources, as raw materials for the industrialization process. Then it raises the waste of the industry which is the main cause of the environmental crisis facing mankind.

4. The existence of poverty, the problem of poverty is not a direct cause of environmental damage, but 
because the problem of poverty is the cause of ignorance and ignorance, then here then unconsciously or realized as the cause of the occurrence and the onset of environmental destruction.

In every development planning, especially the development of industry (mining) is highly recommended to pay attention to the problem of natural sustainability, so that the environmental pollution caused by it does not exceed the threshold required. This is intended so that the continuity of the ecosystem (the reciprocal relationship between humans and the natural environment) we do not suffer damage so that changes in environmental governance are not far from the beginning. Therefore, there can be no release of the relationship between ecology/environment and development planning, as follows:

1. The development planner (government or private), before planning a development must know exactly how the state of the area or region to be exploited, meaning preliminary research (feasibility study) is highly recommended to be done carefully.

2. The development planner should pay attention to the balance of the natural and social environment so that at the time of exploration there are no gaps, especially social inequalities.

3. A plan in it contains also the will (endeavor) about the use of resources (raw materials) that exist.

4. Planning that is prepared should pay attention to the principles of continuity, such as the economy of the surrounding community and the arrangement of the environment at the end and completion of activities.

The details of the four ecological relationships and planning of collateral can be seen clearly in the following diagram.

Figure 2. Human Relationship System and Development Planning

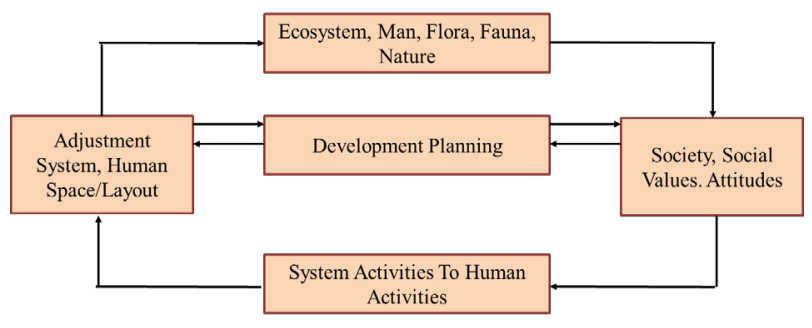

The talk of environmental pollution is nothing new for our nation. Not a few environmental problems faced by this nation, be it the immersion of air, water, encroachment of forests both by HPH holders and by the general public, not even escape also included in this problem is the damage to the social environment. Both natural damage and social damage being caused by human beings themselves.

This is what the people of South Minahasa and Bolaang Mongondow felt [22]. This condition is certainly not expected to be felt by the people in North
Minahasa. Thus, it should be as early as possible (although it is too late), to find solutions to overcome environmental problems, especially pollution caused by heavy metal waste from people's mine waste and that will happen if pt operates. MSM in East Likupang. Our consideration is not between opening or closing mining activities, but how we regulate waste treatment so that there are no social conflicts or conflicts of interest to the problem.

\section{CONCLUSION}

Based on the discussion of the results of the research that has been stated above, it can be concluded that: In order not to experience the same, efforts need to be prepared against environmental pollution, both by the government and by the private sector. In every smallscale gold mining planning, it is necessary to attach Environmental Management Efforts (UKL) and Environmental Monitoring Efforts (UPL) and in largescale mining, it is necessary to include the AMDAL and in the AMDAL the study of social issues needs to be carefully considered.

a. In every mining area both small and large-scale mining potential conflicts are very easily triggered by any situation.

b. To avoid the occurrence of social problems in mining areas, especially in the PT MSM area, it is necessary to monitor mining activities regularly by the government, especially UKL and UPL so that there are no social problems that lead to social insecurity or horizontal or vertical conflicts.

\section{ACKNOWLEDGMENTS}

We would like to express our gratitude to the Dean of the Faculty of Social Sciences, Manado State University who has provided support in writing this article. Not to forget we also thank all citizens in Lolak Subdistrict Bolaang Mongondow North Sulawesi who have been willing to participate in this research.

\section{REFERENCES}

[1] W. S. Bayu, Dinamika Konflik dalam Transisi Demokrasi, Informasi Potense Konflik dan Potensi Integrasi Bangsa (Nation and Character Building). Yogyakarta: INPEDHAM, 2004.

[2] Herdiansyaha and Herdis, "Conflict Management of Renewable Natural Resources in the Border of Indonesia-Malaysia: Sustainable Environmental Approach," ELSEVIER, Procedia Environ. Sci., vol. 20, pp. 444 - 450, 2014.

[3] F. Kerebungu and S. Fathimah, "Pembangunan PLTA Palu-3 (Kajian Sosiologis-Antropologis atas Gagalnya Pembangunan PLTA Palu-3 di Kabupaten Donggala Sulawesi Tengah)," Indones. J. Sociol. Educ. Dev., vol. 2, no. 1, pp. 
$19-25,2020$.

[4] D. Avcı and C. Fernández-Salvador, "Territorial dynamics and local resistance: Two mining conflicts in Ecuador compared," Extr. Ind. Soc., vol. 3, no. 4, pp. 912-921, 2016, doi: 10.1016/j.exis.2016.10.007.

[5] X. Yang, H. Zhao, and P. Ho, "Mining-induced displacement and resettlement in China: A study covering 27 villages in 6 provinces," Resour. Policy, vol. 53, no. July, pp. 408-418, 2017, doi: 10.1016/j.resourpol.2017.07.001.

[6] C. H. Oh, J. Shin, S. H. Ho, and W. T. S. Ii, "Conflicts between mining companies and communities: Causes and resolution approaches," Proceedings, 2018, doi: https://doi.org/10.5465/AMBPP.2018.17753abst ract.

[7] F. Triscritti, "Mining, development and corporate-community conflicts in Peru," Community Dev. J., vol. 48, no. 3, pp. 437-450, 2013, [Online]. Available: https://doi.org/10.1093/cdj/bst024.

[8] M. Nazir, Metode Penelitian, Cetakan Pe. Jakarta: Ghalia Indones, 2005.

[9] Harsojo, Pengantar Antropologi. Bandung: Binacipta, 1988.

[10] Koentjaraningrat, Pengantar Ilmu Antroplogi. Jakarta: Rineka Cipta, 1990.

[11] M. M. Poloma, Sosiologi Kontemporer. Jakarta: Raja Grafindo Persada, 1994.

[12] R. Collins, Conflict of Sociology. New York: The Free Press, 1975.
[13] R. Gramsci, 1971. Selection from the Prision Notebooks. Terjemahan: Raiza, Wahyudi Gafina, Dkk. Surabaya: Pustaka Promethea, 2000.

[14] R. Dahrendrof, Class and Class Conflict in Industrial Society. California: Stanford University Press, 1959.

[15] L. Coser, The Functions of Social Conflict. New York: The Free Press of Clencoe, 1959.

[16] T. R. Gurr, Why Men Rebel. New York: Princeton University Press, 1970.

[17] Crawford, Beverly, and R. D. Lipschutz, Culture and Politics in Indonesia. Berkeley: UNiversity of California Press, 1988.

[18] F. Steve, Etnicity: Racism, Class, and Culture. New York: Rowman \& Littlefield Publishers, 1999.

[19] W. O. Abuya, "Mining conflicts and Corporate Social Responsibility: Titanium mining in Kwale, Kenya," Extr. Ind. Soc., vol. 3, no. 2, pp. 485-493, 2016, doi: 10.1016/j.exis.2015.12.008.

[20] E. Salim, Pembangunan Berwawasan Lingkungan. Jakarta: LP3ES, 1991.

[21] I. N. Beratha, Penambangan Berwawasan Lingkungan. Jakarta: Bumi Aksara, 1991.

[22] F. Kerebungu, S. Fathimah, and T. Pangalila, "Social Conflict in Community (Study On Agrarian Conflict in Lolak District, Bolaang District, Mongondow, North Sulawesi)," Atl. Press, vol. 473, no. Icss, pp. 211-214, 2020. 